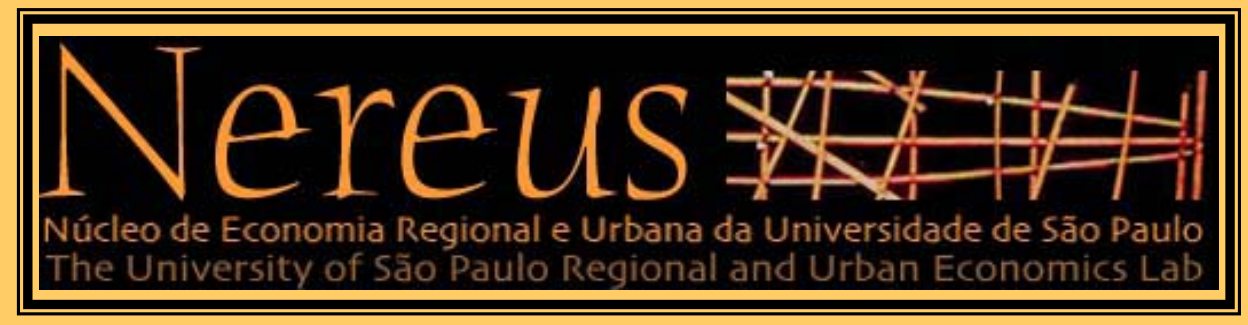

\title{
WHO IN BRAZIL WILL GAIN FROM GLOBAL TRADE REFORMS?
}

Carlos R. Azzoni Jonathan Brooks Joaquim Guilhoto Scott McDonald

TD Nereus 12-2005

São Paulo 2005 


\title{
Who in Brazil Will Gain from Global Trade Reforms?
}

\author{
Carlos Azzoni (University of São Paulo), Jonathan Brooks (OECD and FAO), Joaquim \\ Guilhoto (University of São Paulo) and Scott McDonald (University of Sheffield)*
}

\begin{abstract}
The potential impacts of multilateral trade liberalisation on developing countries are the subject of numerous controversies. One particular concern is that Brazil, a major agricultural exporter and a country with one of the world's most unequal income distributions, will reap a substantial share of the potential benefits to developing countries from agricultural trade reform, and that most of those benefits will go to large scale commercial farmers rather than the country's smallholders. This claim is explored via a global general equilibrium model and a national model of Brazil containing multiple agricultural and non-agricultural households. Brazil is found to account for nearly one-half of all the benefits to developing countries deriving from global agricultural trade reform. These gains are associated with improvements in the welfare of each group and a lower incidence of poverty. Large scale producers gain more than smallholders as they tend to be relatively specialised in export products, but there are important gains to agricultural employees, who are relatively poor, and to urban households, who benefit from the expansion of the agro-food sector. Overall, there is no discernible impact on income inequality, and no evidence that the gains to commercial farmers occur at the expense of poorer households.
\end{abstract}

Keywords: Brazil, trade liberalisation, poverty, inequality, agriculture.

\footnotetext{
* Corresponding author: Jonathan Brooks (jonathan.brooks@fao.org). The authors are grateful to Joe Dewbre and Hsin Huang, who provided the global results, and to Fernando Gaiger, Eduardo Amaral Haddad and Tatiane de Menezes, who assisted in development of the national model.
} 


\section{Introduction}

In referring to the current round of WTO trade negotiations as the Doha Development Agenda, trade policy makers have fostered the notion that multilateral trade reform has the potential to contribute to growth and poverty reduction in developing countries. Yet there is no clear consensus on exactly how trade reform is supposed to further economic development: for some it is through providing developing countries with the scope to trade their way out of poverty; for others it derives from granting developing countries exemptions that would spare their infant industries from global competition. The G20 coalition of developing countries, formed at the Cancún Trade Ministerial in 2003, is itself ambivalent on this issue (Narlikar and Tussie, 2004).

Among academic researchers, there is similarly controversy over how developing countries will be affected by multilateral reforms in general and by agricultural trade reforms in particular. On the plus side, many developing countries have a comparative advantage in this most protected of sectors and so stand to benefit from liberalisation (Anderson and Martin, 2005). Yet it has been pointed out that a large number of net exporters produce tropical products that are not in competition with the highly protected temperate products of OECD countries, and also that there are many net importers of food products who are likely to see their food import bills rise (relative to what they would otherwise be) as a result of reforms (Valdés and McCalla, 1999). A further counter-argument is that developing country exporters often benefit from trade preferences and could lose if global tariff cuts reduced the margin of their preferences over other exporters. On balance, these arguments have been found to qualify the claim that developing countries will benefit from agricultural trade reforms, but not to overturn it (OECD, 2005a; Tangermann, 2005).

A related controversy concerns the distributional impacts of reforms. It is suggested that those developing countries that stand to benefit from agricultural reforms will be efficient middle income exporters rather than poor countries, and that within these countries it is richer export-orientated 
commercial producers who will reap the benefits at the expense of poorer smallholders (Madeley, 2000). There are specific concerns that Brazil, a major agricultural powerhouse and a country with one of the world's worst income distributions, will reap a substantial share of the overall gains from gains from agricultural trade reform, and yet that the country's smallholders will be excluded from the benefits. Thus it is argued that global trade reforms could worsen the country's income distribution, and possibly exacerbate poverty. This paper explores this particular element of the Doha debate.

The global and national welfare effects of multilateral trade reforms and reforms to domestic farm programmes are calculated using GTAPEM, a modified version of the standard GTAP model developed by the OECD. ${ }^{1}$ The changes to Brazil's export and import prices associated with these reforms are fed exogenously into a national CGE model of Brazil, which embeds multiple households categories, classified according to their economic function. This makes it possible to examine the distributional impacts of trade reform within Brazil; in particular, the gains and losses to producers, farm labourers, and urban consumers at varying levels of income. The paper is organised as follows. Section 2 describes the overall welfare impact of reforms on Brazil, and situates these gains relative to the impacts on other countries. Section 3 examines how these gains are distributed across different household types within the Brazilian economy and examines the implications for income distribution. Section 4 concludes with a discussion of how the results can illuminate discussions of trade policy reform.

\section{Aggregate welfare impacts of trade and agricultural policy reforms}

The effects on the Brazilian economy of multilateral trade reforms and reforms to domestic farm programmes are calculated using GTAPEM. In GTAPEM, the standard GTAP model is modified to

1. GTAP is a global general equilibrium trade model that is widely used in applied agricultural and trade policy analysis. GTAPEM is the name given to the modified version of the GTAP model that draws on the OECD’s Policy Evaluation Model (PEM). 
provide a better representation of the allocation of land between alternative uses, and to accommodate a representation of policy interventions that is consistent with the way in which support is classified and measured by the OECD. In addition, the data used in this analysis take account of the trade preference schemes operated by a number of countries. These schemes are particularly important in the case of Brazil, which rarely benefits from preferential tariffs and therefore stands to gain from tariff reforms that reduce their significance. ${ }^{2}$

The policy reform scenario examined comprises a 50\% reduction in tariffs for all countries and all sectors, a 50\% cut in agricultural export subsidies for all countries, and a 50\% reduction in domestic farm support in OECD countries plus Brazil and China. The results are comparative static, i.e. they show the one-off gains from a change in policies, and are based on data for 2001. Accordingly, recent policy changes, including the US farm bill and the introduction of the single farm payment in the European Union, are not considered. Policy changes as a result of China's WTO accession are also excluded, with the exception of tariff reductions made on grains and oilseeds.

The results for Brazil depend, among other things, on the structure of its existing trade relationships, and on the extent of protection in export and import markets. Table 1 summarises the average tariffs levied and faced by Brazil, and compares those rates with the average tariffs levied and faced by OECD countries and by non-OECD countries.

2. The GTAPEM model is documented in OECD (2005a), while the national level analysis is described more fully in OECD (2005b). 
Table 1. Tariffs levied and faced: comparative data

\begin{tabular}{|c|c|c|c|c|c|c|}
\hline & \multicolumn{3}{|c|}{ Tariffs levied (\%) } & \multicolumn{3}{|c|}{ Tariffs faced (\%) } \\
\hline & Brazil & OECD & $\begin{array}{c}\text { non- } \\
\text { OECD }\end{array}$ & Brazil & OECD & $\begin{array}{c}\text { non- } \\
\text { OECD }\end{array}$ \\
\hline Paddy rice & 0 & 190 & 5 & 23 & 72 & 58 \\
\hline Vegetables/fruit & 4 & 14 & 16 & 6 & 8 & 12 \\
\hline Plant fibres/other crops & 8 & 5 & 10 & 9 & 5 & 7 \\
\hline Wheat & 0 & 30 & 11 & 1 & 24 & 16 \\
\hline Coarse grains & 1 & 63 & 10 & 99 & 30 & 44 \\
\hline Oilseeds & 0 & 44 & 8 & 7 & 7 & 18 \\
\hline Dairy products & 6 & 47 & 16 & 11 & 23 & 11 \\
\hline Processed rice & 0 & 130 & 14 & 9 & 64 & 23 \\
\hline Processed sugar & 14 & 60 & 22 & 26 & 31 & 48 \\
\hline Ruminant meat & 1 & 21 & 14 & 62 & 20 & 26 \\
\hline Non-ruminant meat & 11 & 32 & 19 & 16 & 26 & 13 \\
\hline Other processed food & 10 & 9 & 22 & 14 & 11 & 10 \\
\hline Manufacturing & 10 & 2 & 10 & 4 & 3 & 3 \\
\hline Textiles, wearing apparel, leather & 15 & 8 & 18 & 7 & 7 & 11 \\
\hline Services & 0 & 0 & 0 & 0 & 0 & 0 \\
\hline \multicolumn{7}{|l|}{ Simple Average } \\
\hline Agriculture & 5 & 54 & 14 & 23 & 27 & 24 \\
\hline Primary & 2 & 36 & 7 & 17 & 19 & 17 \\
\hline Processed & 7 & 50 & 18 & 23 & 29 & 22 \\
\hline
\end{tabular}

Note: For each country, the trade-weighted tariff levied and faced is calculated for each product based on bilateral data. The OECD and non-OECD averages are then a simple average across relevant countries in the database.

Source: GTAP database, version 6.

On the import side, Brazil's average tariffs are relatively low, at $2 \%$ for primary agricultural products, $7 \%$ for processed agricultural products, and $10 \%$ for manufactures. Brazil is one of the few countries in the world for which agricultural tariffs are lower than non-agricultural tariffs. The tariffs that Brazil faces on its agricultural exports are considerably higher than those it levies, at $17 \%$ for primary products and $23 \%$ for processed products. Brazil encounters approximately the same degree of tariff escalation as other developing countries, and tends to levy higher tariffs on non-agricultural products than it faces, which is also the case in most developing countries. Brazil's own agricultural tariffs are very low on average, partly because a large share of the country's imports enters duty free 
from MERCOSUR countries. Given also that imports account for just $4 \%$ of consumption, the welfare impacts from liberalisation are expected to be small.

Primary and processed agriculture account for $13 \%$ of the value of production, with $16 \%$ of this total exported. In the base year, agriculture is not more export-oriented than the manufacturing or textile sectors (where the shares of exports in production are almost identical). Thus the benefits from improved agricultural market access are not, in this analysis, attributable to any relative outward orientation (tradability) of this sector. Non-agricultural sectors account for the majority of output, with manufactures accounting for $30 \%$, and services $58 \%$. On the export side, tariffs faced on manufactures are much lower than for agricultural products, so the gains are expected to be relatively less important. As imports of manufactures exceed exports, and Brazil's tariffs are higher than for other sectors, a larger share of the efficiency gains from reform would be expected to derive from lower domestic prices, as Brazil reduces its own tariffs. The net effect, however, also depends on terms-of-trade effects, and would be dampened to the extent that import prices rise.

The welfare impacts of the $50 \%$ reform scenario described above are summarised in Table 2 . In overall terms, OECD countries reap about three-quarters of the global welfare gains. About half of these gains come from liberalising their own agricultural policies, the rest from lower tariffs on manufactures in non-OECD and OECD countries. Agricultural policy reforms in non-OECD countries are relatively less important. For non-OECD countries, the biggest gains come from lower OECD country tariffs on manufactures. There are also significant gains from reforms to agricultural policies in both OECD and non-OECD countries. 
Table 2. Welfare effects of multilateral trade reform, equivalent variation USD million

\begin{tabular}{lrrrrr}
\hline & $\begin{array}{c}\text { Total } \\
\text { Welfare }\end{array}$ & $\begin{array}{r}\text { OECD } \\
\text { Agriculture }\end{array}$ & $\begin{array}{r}\text { non-OECD } \\
\text { Agriculture }\end{array}$ & $\begin{array}{r}\text { OECD } \\
\text { Manufacturing }\end{array}$ & $\begin{array}{r}\text { non-OECD } \\
\text { Manufacturing }\end{array}$ \\
\hline World & 44268 & 23361 & 3124 & 6694 & 11357 \\
OECD & 33459 & 21407 & 1871 & -248 & 10680 \\
Non-OECD & 10809 & 1954 & 1253 & 6943 & 677 \\
Brazil & 1730 & 1178 & 94 & 367 & 96 \\
China & 3739 & -73 & -199 & 3373 & 635 \\
India & 1723 & 72 & 544 & 378 & 735 \\
South Africa & 253 & 69 & 25 & 23 & 137 \\
\hline
\end{tabular}

Source: OECD (2005b).

Agricultural trade reform is particularly important to Brazil, accounting for two-thirds of the country's total welfare gains of USD 1.7 billion. Most of these benefits derive from agricultural policy reforms in OECD countries. Indeed, Brazil accounts for a large share of the gains to all developing countries deriving from reforms to agricultural policies in OECD countries.

The specific results for Brazil differ from the overall pattern for developing countries. Policies governing so-called "south-south" agricultural trade are less important than for most developing countries. In addition, the benefits deriving from reforms in the manufacturing sector are much less important in relative terms (just $27 \%$ of the total gains), with most of the USD 460 million gain coming from reforms in OECD countries. The efficiency gains to Brazil from lowering its own tariffs on manufactures are to a large extent offset by rising import prices.

The results contrast markedly with those for China, India and South Africa - three other important developing country agricultural traders and members of the G20 coalition. In the case of China, most of the benefits come from lower tariffs on manufactures in OECD countries, while for India and South Africa, it is tariffs on manufactures in non-OECD countries that matter most. These differences partly explain the divergence of priorities within the G20. 
Within agriculture, world price changes are expected to be modest for most commodities, with prices for the lowest cost exporting country expected to increase by between $2 \%$ and $6 \%$. For Brazil, the major sectors benefiting are beef, non-ruminant meats, oilseeds and other crops (including coffee, cotton and tobacco), as well as the processed food sector. The benefits to the sugar industry are relatively small, due to modest changes in world prices (2\%).

Figure 1 indicates that the simulated policy reforms would boost returns to labour and capital in both agricultural and non-agricultural sectors. The returns to factors employed in agriculture increase much more than the returns to factors employed in other sectors, causing more factors to be retained in agriculture than would otherwise be the case. On the other hand, there is little difference in the returns to capital and (skilled or unskilled) labour in either the agriculture or non-agriculture sub-sector. This suggests that the distributional effects of reform depend more on the shift of resources between sectors than on changes in relative factor returns within any sector. The distribution of these inter-sectoral changes throughout the Brazilian economy is now explored.

Figure 1. Changes in factor returns in agricultural and non-agricultural sectors

Per cent

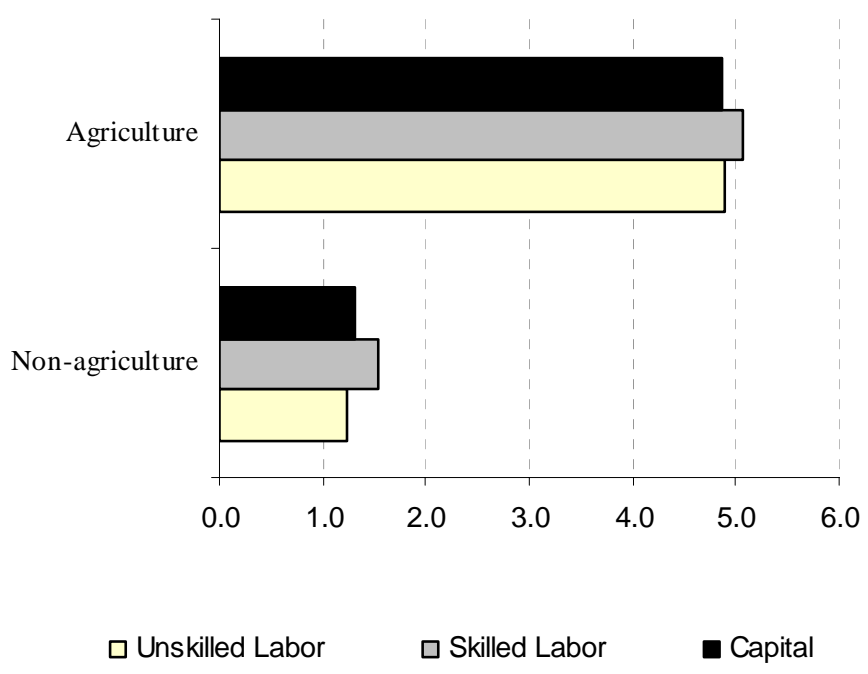

Source: GTAPEM. 


\section{Household impacts of trade and agricultural policy reforms}

Brazil has a large and heterogeneous agriculture with a commercial export-oriented sector co-existing with a family farm sector that includes many subsistence and semi-subsistence households. It is also a highly urbanised country, with large numbers of poor consumers whose real incomes are dependent on the price of food. This section uses a Social Accounting Matrix (SAM) and an associated Computable General Equilibrium (CGE) model to consider how the incomes of these diverse constituencies will be affected by global reforms.

The SAM describes the generation and distribution of income in the economy in a consistent manner. It comprises six types of accounts: activities; commodities; the current accounts of domestic institutions, divided into households, firms and governments; the capital accounts; and the rest of the world account. The key attribute of the SAM developed here is its rich sectoral and household level detail. Thus there are 30 activities, of which 9 are in primary agriculture and 15 are in agribusiness; and 40 products, of which 17 are agricultural and 19 of the remaining 23 are agribusiness or strongly agriculture related. There are 10 household accounts, comprising four categories of family farm household, ordered by economic size; one category of "commercial” farm households; one category of wage-earning agricultural employees; and four categories of urban household, ordered by income quartile. In addition, factor payments (land, labour and capital) are identified for each household according to the activities from which they derive. With government, trade and tax accounts, the end result is a large matrix $(183 \times 183)$. All totals match the national income accounts of 1999 . $^{3}$

In order to provide this level of detail and complete the economy-wide picture, several datasets had to be combined. In particular, information on the income sources and expenditure patterns of the different household types had to be compiled from a variety of sources. A key decision concerned the

3. The full SAM is available on the OECD website (www.oecd.org/agr/ete). 
appropriate choice of household groupings. For agricultural households, the choice of categories follows that of a FAO/INCRA study (2000, based on 1995/96 Agricultural Census data). ${ }^{4}$ This breakdown facilitated the combining of data from various sources on the basis of common information, thus permitting a fairly rich representation of the characteristics of smaller (and relatively poor) households. Table 3 provides summary information for the different categories of household at the time of the 1995/96 Census.

Table 3. Structural characteristics of Brazilian farms, 1995/96.

\begin{tabular}{|c|c|c|c|c|c|c|c|c|c|}
\hline & \multicolumn{2}{|c|}{ Number of Farms } & \multicolumn{3}{|c|}{ Area } & \multicolumn{2}{|c|}{ Production Value } & \multicolumn{2}{|c|}{ Employment } \\
\hline & 1000 & $\%$ & $10000 \mathrm{Ha}$ & $\%$ & Average Size & BRL Million & $\%$ & 1000 & $\%$ \\
\hline Family farms & 4139 & 85.2 & 107768 & 30.5 & 26.0 & 18118 & 37.9 & 13780 & 76.9 \\
\hline Type 1 & 1916 & 39.4 & 31599 & 8.9 & 16.5 & 1943 & 4.1 & 5569 & 31.1 \\
\hline Tyре 2 & 823 & 16.9 & 18218 & 5.2 & 22.1 & 1707 & 3.6 & 2785 & 15.5 \\
\hline Type 3 & 994 & 20.4 & 33810 & 9.6 & 34.0 & 5311 & 11.1 & 3683 & 20.5 \\
\hline Tyре 4 & 407 & 8.4 & 24141 & 6.8 & 59.4 & 9156 & 19.2 & 1743 & 9.7 \\
\hline Commercial & 554 & 11.4 & 240042 & 67.9 & 432.9 & 29140 & 61.0 & 3557 & 19.8 \\
\hline TOT AL $^{1}$ & 4860 & 100.0 & 353611 & 100.0 & 72.8 & 47796 & 100.0 & 17931 & 100.0 \\
\hline
\end{tabular}

1. Total includes other cases, such as churches and government offices. Source: FAO/INCRA (2000).

4. In order for a farm to qualify as a "family farm", the following criteria must be met: i) the owner manages the farm; ii) the use of family labour exceeds that of hired labour; and iii) farm area is smaller than a regionally defined maximum size. Family farms are then grouped according to net income, defined as the difference between revenue (including monetary and self-consumption) and expenditures. The four groups are ordered according to the regional value of the daily payment to a hired rural worker (augmented by 20\%), which is considered as the regional opportunity cost. For category 1 , net farm income is less than half opportunity cost; for category 2 it is between $1 / 2$ and full opportunity cost; for category 3 between opportunity cost and 3 times opportunity cost; and for category 4 it is greater than 3 times opportunity cost. Some secondary criteria were also employed, such as the share of the main product in total revenue, sales revenue as a proportion of total production value, and the intensity of use of hired labour. 
Overall, family farms accounted for 85\% of all farms in Brazil in 1995/96, but were responsible for just 38\% of production. Commercial farms operate on a much larger scale, with an average size seven times that of the largest group of family farms. The commercial average of 430 ha conceals wide heterogeneity, with farms of over 10000 ha no longer uncommon in the Centre West. Commercial farms accounted for nearly $20 \%$ of agricultural employment, due to the important (albeit declining) use of wage labour.

Table 4 shows how incomes and expenditures vary across the different household groups. Family farming accounts for $14.4 \%$ of the total population, while commercial farming accounts for just $1.7 \%$. Among the overall category of family farms, a minority of the population corresponding to Type 4 equal to those in the commercial group - have relatively high incomes and are similar in their consumption patterns to those in commercial farm households. The main difference is that these households obtain one-third of their income from off-farm sources. A comparison of Table 3 and Table 4 suggests that there are alternative paths to achieving the same standard of living within agriculture. One possibility is large-scale agricultural operations; in other circumstances, smaller-scale enterprises with diversified income sources may be equally viable.

Table 4. Income and expenditure patterns of Brazilian households

\begin{tabular}{|c|c|c|c|c|c|c|c|c|c|c|c|c|c|}
\hline & \multirow{2}{*}{$\begin{array}{c}\text { Number } \\
\text { of } \\
\text { households } \\
1000\end{array}$} & \multirow{2}{*}{$\begin{array}{c}\text { Share } \\
\text { of } \\
\text { households } \\
\%\end{array}$} & \multirow{2}{*}{$\begin{array}{c}\text { Number } \\
\text { of } \\
\text { persons } \\
1000\end{array}$} & \multirow{2}{*}{$\begin{array}{c}\text { Share } \\
\text { of } \\
\text { population } \\
\%\end{array}$} & \multirow{2}{*}{$\begin{array}{c}\text { Average } \\
\text { income } \\
\text { BRL/month }\end{array}$} & \multicolumn{4}{|c|}{$\%$ of Income From } & \multicolumn{4}{|c|}{$\%$ of Expenditure on } \\
\hline & & & & & & \begin{tabular}{|c|} 
Raw \\
agricultural \\
products
\end{tabular} & $\begin{array}{l}\text { Processed } \\
\text { food } \\
\text { products }\end{array}$ & $\begin{array}{c}\text { All } \\
\text { food } \\
\text { products }\end{array}$ & $\begin{array}{c}\text { Other } \\
\text { activities }\end{array}$ & \begin{tabular}{|c|} 
Raw \\
agricultural \\
products
\end{tabular} & $\begin{array}{l}\text { Processed } \\
\text { food } \\
\text { products }\end{array}$ & $\begin{array}{c}\text { All } \\
\text { food } \\
\text { products }\end{array}$ & $\begin{array}{c}\text { Other } \\
\text { activities }\end{array}$ \\
\hline Family Agriculture 1 & 1997 & 4.3 & 10443 & 6.3 & 38.4 & 45.4 & 1.3 & 46.8 & 53.2 & 20.7 & 44.0 & 64.8 & 35.2 \\
\hline Family Agriculture 2 & 1053 & 2.3 & 4686 & 2.8 & 86.9 & 48.1 & 1.8 & 49.9 & 50.1 & 18.0 & 41.5 & 59.5 & 40.5 \\
\hline Family Agriculture 3 & 1693 & 3.7 & 6002 & 3.6 & 159.6 & 63.0 & 1.3 & 64.3 & 35.7 & & 37.0 & 37.0 & 47.9 \\
\hline Family Agriculture 4 & 968 & 2.1 & 2883 & 1.7 & 438.5 & 65.4 & 0.7 & 66.1 & 33.9 & 6.0 & 17.7 & 23.8 & 76.2 \\
\hline Commercial Farms & 740 & 1.6 & 2882 & 1.7 & 489.3 & 100.0 & & 100.0 & & 8.2 & 17.9 & 26.1 & 73.9 \\
\hline Agricultural Employees & 2661 & 5.7 & 10927 & 6.6 & 118.2 & 100.0 & & 100.0 & & 9.6 & 32.3 & 41.9 & 58.1 \\
\hline Urban Household 1 & 7430 & 16.0 & 32232 & 19.3 & 62.7 & & 3.5 & 3.5 & 96.5 & 9.6 & 29.7 & 39.3 & 60.7 \\
\hline Urban Household 2 & 8744 & 18.9 & 32231 & 19.3 & 151.7 & & 4.6 & 4.6 & 95.4 & 6.7 & 23.9 & 30.6 & 69.4 \\
\hline Urban Household 3 & 9824 & 21.2 & 32233 & 19.3 & 284.3 & & 4.6 & 4.6 & 95.4 & 5.3 & 17.7 & 23.0 & 77.0 \\
\hline Urban Household 4 & 11239 & 24.2 & 32234 & 19.3 & 1021.0 & & 3.4 & 3.4 & 96.6 & 2.7 & 8.5 & 11.2 & 88.8 \\
\hline All Households & 46349 & 100 & 166753 & 100 & 328.13 & 7.95 & 3.43 & 11.38 & 88.62 & 4.85 & 15.07 & 19.91 & 80.09 \\
\hline
\end{tabular}

Source: USP SAM. 
The two poorest categories of farm household obtain more than half their income from sources other than farm production, and spend an even greater share on food and agricultural products. Hence, when examining the impacts of reform on these groups it is crucial to consider cost-of-living impacts, as well as the effects on revenues. Commercial farms and the richest category of family farms have per capita incomes that place them between the third and fourth quartile of urban households. Although agricultural incomes are unevenly distributed, these farmers generate an average income that is less than half that received by the richest $25 \%$ of the urban population.

In terms of total income, the poorest quartile of the urban population has an average income between that of the poorest and second poorest family farm group. However, this group accounts for $19 \%$ of the total population, compared with $9 \%$ of the population for the two poorest categories of farm households. Thus the impacts of agricultural policy reform may be widespread across poor urban households, even though the impacts may be less acute than for poor farmers.

It is important to note that there is considerable regional heterogeneity within the farm sector. In the richer South and South East regions, 90.5\% of establishments are considered family farms. These farms account for $43.8 \%$ of total area and $43.3 \%$ of loans and are responsible for $57.1 \%$ of agricultural production value in the region (FIPE, 2004). In the poorer North East region, family-farming accounts for a similarly high proportion of total farms (88.3\%) and occupies a similar share of total area (43.8\%). However, its share in the value of regional production is much lower at $43 \%$, and it receives only $26.8 \%$ of regional loans. These differences are reflected in farm incomes, which average BRL 5152 in the South and South East, compared with BRL 1159 in the North East.

Table 5 shows the share of each type of agricultural household in the value of production by sector. These data are summarised in Figure 2 below. Commercial farms dominate most product categories, but tend to be more important in the sectors that dominate production and exports. Family farms account for the majority of production of tobacco, manioc, beans, vegetables, pigs, bananas and 
milk. Moreover, it is important to recognise that some family farms obtain a substantial share of their income from activities dominated by commercial farms. Table 6 recasts the same information in terms of the share of income that comes from each sector, for each household type. The figures naturally obscure the fact that individual households tend to be specialised in fewer products; but they do suggest that higher prices for dairy products, hogs, and staples such as beans and manioc will have a much bigger direct impact on the incomes of low-income farmers than higher prices for soybeans, sugar or cattle.

Figure 2. The composition of production value, by farm type

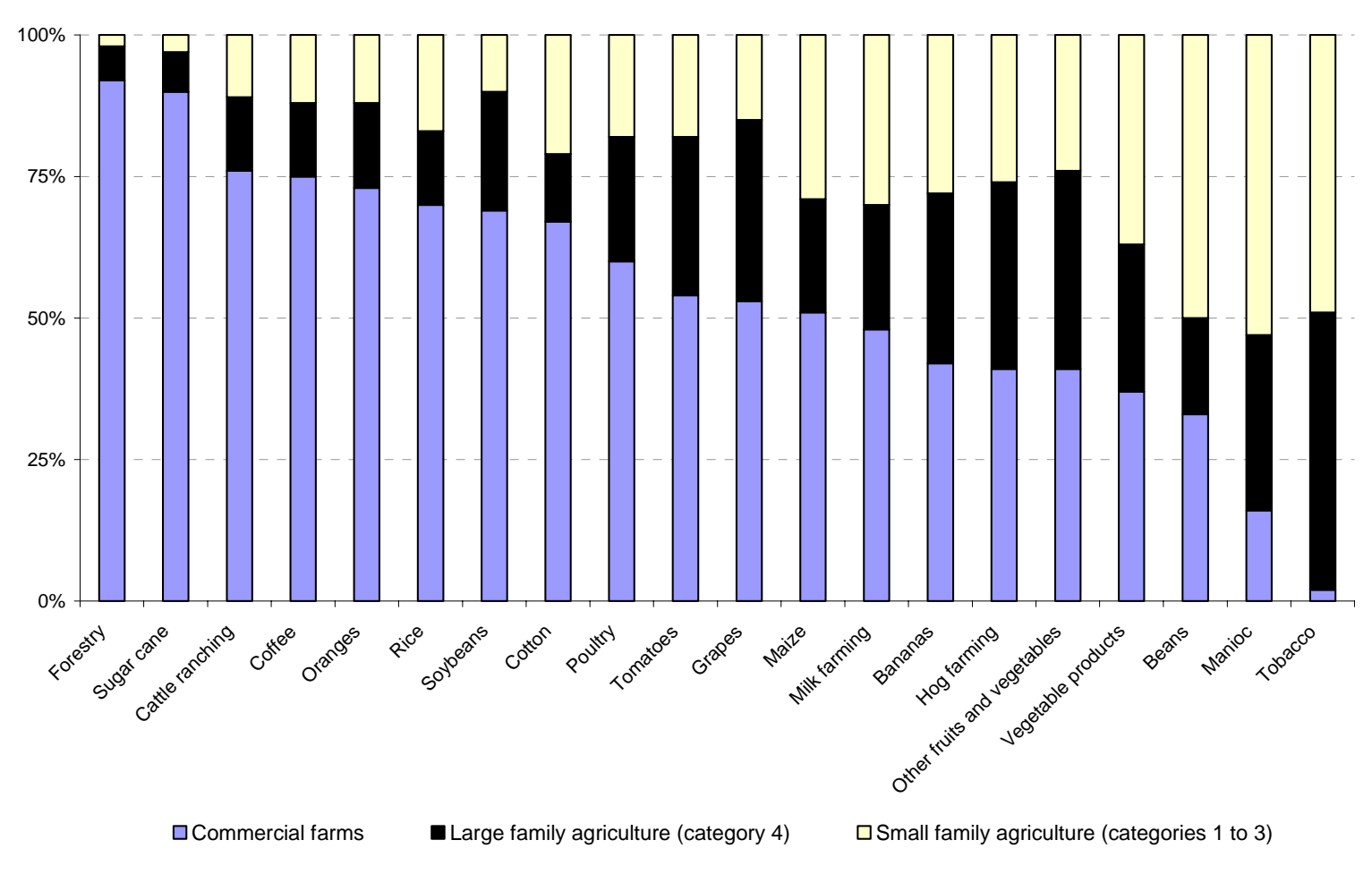

Source: USP SAM.

On the expenditure side, most food products account for a progressively smaller share of budgets as incomes increase (Table 7). Nevertheless, food accounts for more than $40 \%$ of expenditures of the two poorest categories of farm household, and for at least $40 \%$ of the expenditures of half the urban population. Non-monetary food expenditures are particularly important for poor rural families. The share of income spent on housing increases as income rises, but, other things equal, housing 
expenditures are more important for urban households. More generally, richer households have more diversified consumption structures, and spend relatively more on health and education.

\section{Model results}

The SAM for Brazil underpins a CGE model that is used to estimate the distributional impacts of the multilateral trade reform package described in the previous section. The analysis in this section takes the import and export price changes from the preceding GTAPEM simulation and imposes these as exogenous shocks to the model. At the same time, Brazil undertakes the same amount of reform itself, cutting all tariffs by $50 \%$ and reducing its agricultural subsidies by $50 \% .{ }^{5}$ The simulations were run under alternative assumptions regarding the closure of the model. Specifically, the assumption of full employment was relaxed by assuming that a perfectly elastic supply of unskilled labour was available at the prevailing wage rate, while fiscal neutrality was accommodated by fixing the government budget deficit/surplus and allowing tax rates to vary. The results for all four sets of closure rules are reported, although the preference is for the simulations with unemployed unskilled labour and fiscal neutrality. The aggregate benefits from reform are shown in Figure $3{ }^{6}$

5. Note that the GTAPEM analysis takes account of reforms undertaken by Brazil, but for this analysis it is still necessary to account for the effect that reforms will have on domestic prices.

6. The model is described in McDonald (2005a), with further detail on the simulations and results provided in McDonald (2005b). In general, the results are similar to those found in other general equilibrium studies incorporating household data, notably Hertel et al. (2003) and Bento and Horridge (2005). The main substantive difference concerns the results for non-agricultural households, where the latter studies find that, for some urban households, the adverse effects of price increases can outweigh the benefits deriving from higher profits and wage earnings in the agro-food and nonagricultural sectors. Such differences are to be expected given differences in both the underlying datasets and the shocks applied. 
- In general, the welfare gains are widespread across household types. With the poorer categories of urban and rural household better off, the incidence of poverty falls.

- Inequality among agricultural producer households increases, with larger (and richer) family farm households gaining more than smaller ones.

- At the same time, the total gains to agricultural employees are more than for any other type of agricultural household. Because this group is relatively poor, this counteracts the increase in inequality among agricultural producers.

- Urban households also gain, and their benefits generally increase with income level. The exception is the richest quartile, whose gains are less than those of the second richest group, and in fact loses when there is full employment (because they end up paying more for goods that use unskilled labour).

- The burden of fiscal neutrality is borne disproportionately by the third urban quartile. This reflects a relatively flat income tax structure for the richest $50 \%$ of urban households and greater cost of living increases for the second richest group.

- As a result of these welfare changes, there is expected to be little overall impact on income inequality. 
Figure 3. Equivalent variation in household welfare

USD million

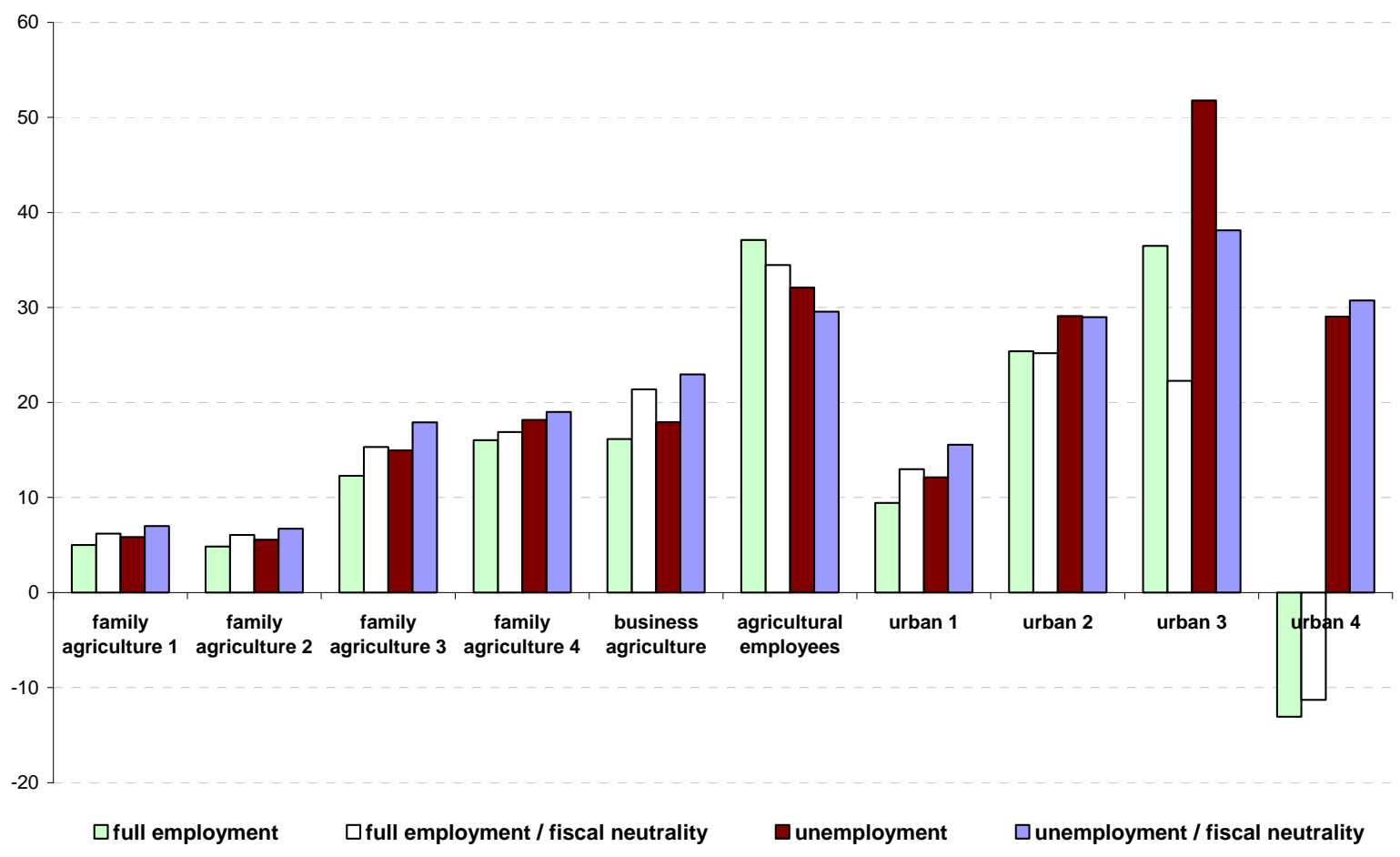

Source: Simulation results.

Given that the above categories contain different numbers of households and persons, further insight can be obtained from the annual changes in welfare per 'person' that are reported in Figure 4. These estimates confirm that, for agricultural households, the welfare gains increase with income, and that the benefits to agricultural households are generally greater than for urban households. ${ }^{7}$

7. The number of members per household tends to decline as income increases. Hence the tendency for richer individuals to gain more than poorer ones (in both rural and urban categories) is more pronounced than the tendency for richer households to benefit more than poorer households. 
Figure 4. Annual changes in welfare per person

USD

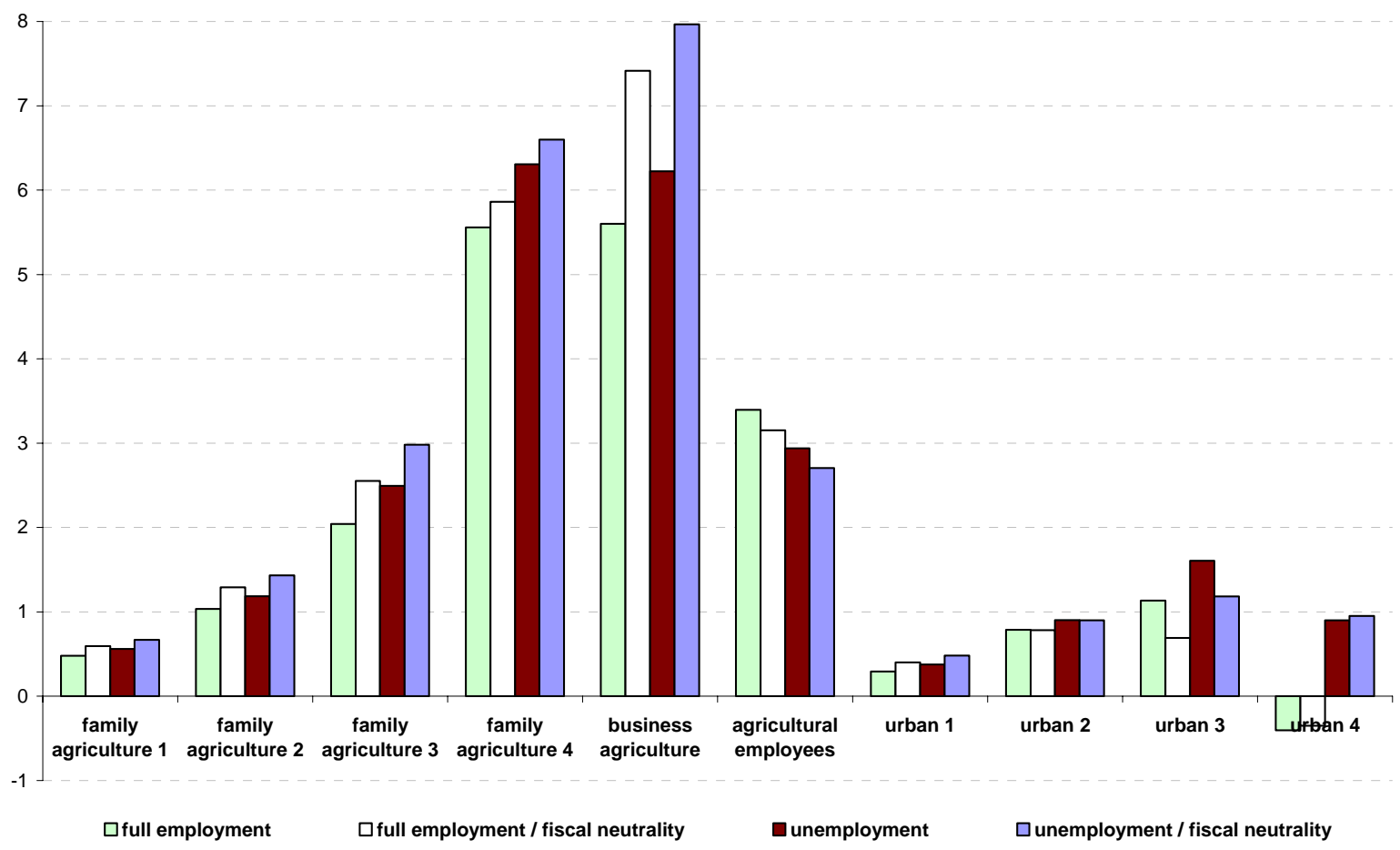

Source: Simulation results.

In order to understand the origins of these welfare gains, it is helpful to examine the underlying changes in factor incomes (which reflect supply responses to changing output prices) and expenditures (resulting from changes in purchaser prices and consumption patterns).

With regard to factor incomes, it is clear that agricultural labour and capital gain proportionally more than non-agricultural labour and capital (Table 8). At the same time, there is a less pronounced tendency for labour and capital income in both agricultural and non-agricultural sectors to increase with the household's income level. ${ }^{8}$ Overall, the reallocation of factor income between agricultural and non-agricultural sectors exceeds the reallocation within each sector.

8. The exception is urban labour income, where the gains are lowest for the richest quartile. 
The changes in household income are shown in Table 9. The reason that richer agricultural households gain more in both relative and absolute terms from increases in land and capital income is that production (and exports) expand more rapidly for those products produced by richer farm households. However, they also gain more from increases in labour income, because the activities that expand most following liberalisation are those using skilled labour.

For urban households the proportionate changes in household incomes are much more even, with the only outlier being the highest income group. The primary reason for this is the relatively high proportion (15\%) of this household's income that comes from transfers by the government. However this is also a very large household group that is likely to contain substantial heterogeneity and consequently the within group variations are likely to be considerable.

Factor income changes provide only a partial explanation for the observed welfare effects. The other element comes from the changes in purchaser prices (see Table 10) and the expenditure patterns of households (see Table 11). In the main, agricultural prices rise, with the notable exceptions of rice, wheat, soybeans and milk. ${ }^{9}$ Processed food prices show mixed effects, while the prices of manufactures and services decline. With lower income households spending relatively more on agricultural products than richer households, and agricultural households similarly spending more than urban households (independent of income), this dampens the overall tendency for welfare to increase more for agricultural households, and to increase with income.

The expansion of exports (see Table 12) is greater in percentage terms for agricultural commodities, although the absolute change in volumes from manufactures and services dominate. On the import side, the proportionate changes in volumes are more dispersed (see Table 13), although

9. The apparently perverse results of negative percentage changes in purchaser prices for sugar and soybean is a consequence of the large supply responses by these activities in response to increased export prices and demand. 
again the absolute changes for manufacturing and services are largest. The combined effects of these changes are incentives to reallocate factors to agricultural activities (see Table 14). The returns to factors employed in agriculture rise by around 3 to $4 \%$, while for other activities returns increase by slightly over $1 \%$.

\section{Discussion}

Brazil is expected to gain significantly from global multi-sector trade liberalisation, and to be one of the principal beneficiaries from agricultural trade and domestic policy reforms. This result is not surprising given Brazil’s importance to world agricultural markets and its specialisation in products that are afforded high protection in OECD countries.

The exploitation of these gains from trade is expected to raise the incomes of all household groups, including the poorest. But it is not expected to have any significant impact on the distribution of income in Brazil. In this respect, our results differ somewhat from those of Bento and Horridge (2005) and Harrison et al. (2004), who predict that reforms will cause incomes of all groups to rise, but also find that global trade reforms will on balance cause Brazil's income distribution to improve, albeit slightly. In both the Bento and Horridge and Harrison et al. papers, trade reform raises the returns to unskilled labour relative to capital, which helps the poor more than other groups. In our study, these benefits to unskilled workers also hold, but agricultural profits, which are specified separately, rise more than other sources of income. The biggest beneficiaries are agricultural wage earners (the fourth poorest of the 10 groups) and commercial producers (the second richest), whose incomes are co-dependent. Richer agricultural families gain more than poorer ones, while agricultural households tend to gain more than twice as much as urban households at the same level of income (i.e. the gains for the third category of agricultural family are similar to those of the second urban quartile). Overall, therefore, there is no linear relationship between existing income level and the extent of gains, 
so any measure of income inequality will depend on the measure adopted. The gains are in fact too small to produce a significant change in the Gini coefficient.

It is important to note that improvements in the average incomes of each household category could mask some adverse impacts on individual households within the poorer family farm categories. Specifically, some households could be net consumers of individual products and cost of living increases could outweigh any gains from products for which they have a surplus. The results may also hide important regional differences. Regional disaggregation would tend to increase the output specialisation of the different categories, but have a more modest impact on the patterns of consumption. This may lead to more varied results, depending on the regional output mix.

The model results are, to some extent, dependent on the assumption that product and input markets function smoothly. In particular, small farmers are assumed to receive the same prices as large ones, and to exhibit the same output response. The sensitivity of the results to this assumption was partially examined by considering a scenario under which the full increase in export supply came from commercial producers. Under these conditions, family farmers were excluded from the direct benefits of reform, but nevertheless gained indirectly through higher domestic prices. But if smaller farmers are not linked into national markets, they could receive no benefit from higher prices, and could in fact lose from factor market impacts, for example if an expansion in commercial production led to higher land rental rates. How likely is this? Analysis of domestic market integration (González-Rivera and Helfand, 2001) suggests that some rural markets are effectively isolated, but most are not. Therefore this is likely to be a local impact rather than one which invalidates the overall conclusion that poorer households will share in the gains from reform.

A further question concerns the links between policy reform and the dynamics of adjustment. If policy reform, by opening new export markets, induces structural change that favours large-scale commercial businesses, then this could accelerate the adjustment pressure on family farm agriculture. 
Whether this is good or bad for small farmers will depend on whether they own or rent land. A final consideration is that agro-food exports are crucial to Brazil's balance of payments situation, and hence to macroeconomic stability. The modelling undertaken here abstracts from these issues, but if a decline in commercial exports were to weaken the current account sufficiently to undermine macroeconomic stability, then that could lead to adverse effects on all incomes.

To summarise, multilateral trade reform is likely to lead to widespread benefits in Brazil. There are three main reasons for this. First, both commercial and family farms are on balance net sellers of exported products whose prices will rise. Second, the potential losses to farms in import-competing sectors have in fact already been incurred by opening up trade within MERCOSUR, so no domestic price declines are expected. Third, non-agricultural households will on balance gain from higher agricultural prices, as the effects of higher profits and wages in the agro-food sector will outweigh the impacts of higher food prices. These gains are reinforced by non-agricultural liberalisation at the global level.

The model results do not alter the fact that small-scale family farms in Brazil face significant adjustment pressures. Trade reform could accelerate these pressures, but they exist anyway. Given the prospect of generally improved welfare, the best response would be through policy to facilitate adjustment, rather than measures that impede one of the economy's main engines. The argument that agricultural reforms should be avoided because the main beneficiaries will be rich Brazilian farmers seems particularly fallacious. 


\section{REFERENCES}

Anderson, K. and W. Martin and D. van der Mensbrugghe (2005), "Market and Welfare Impacts of Doha Reform Scenarios,” Chapter 12 in Agricultural Trade Reform and the Doha Development Agenda, edited by Will Martin and Kym Anderson, The World Bank, Washington, DC, forthcoming.

FAO-INCRA (2000), “Novo Retrato da Agricultura Familiar: O Brasil Redescoberto”, MDA/INCRA, Brasília.

Bento, J. And M. Horridge (2005), “The Doha Round, Poverty and Regional Inequality in Brazil”, Putting Development Back into the Doha Agenda: Poverty Impacts of a WTO, Hertel T. and A. Winters eds., the World Bank, Washington D.C.

FIPE (2004), “The Distributional Effects of Agricultural Policy Reform: The Case of Brazil”, report prepared for OECD, 2004, São Paulo.

González-Rivera, G. and S.M. Helfand (2001), “The Extent, Pattern, and Degree of Market Integration: A Multivariate Approach for the Brazilian Rice Market”, American Journal of Agricultural Economics, Vol. 83(3), pp. 576-592.

Harrison, G.W., T.F. Rutherford, D.G. Tarr, and A. Gurgel (2004), “Trade Policy and Poverty Reduction in Brazil”, The World Bank Economic Review, Vol. 18, No. 3, pp. 289-317.

Hertel, T.W. et al. (2003), "Multilateral Trade Liberalisation and Poverty in Brazil and Chile”, Économie internationale, Vol 94-95, pp.201-233. 
INCRA (National Institute for Colonization and Agrarian Reform) (2005), “II National Reform Plan Brazil”, Special Edition to the World Social Forum 2005.

Madeley, J. (2000), Hungry for Trade: How the Poor Pay for Free Trade, Zed Publishing Ltd.

McDonald, S. (2005a), ‘A Standard Computable General Equilibrium Model Version 5: Technical Documentation', PROVIDE Project Technical Paper 2005:03. Elsenburg, RSA.

McDonald, S. (2005b), “Global Trade Liberalisation and Brazil; A Single Country Computable General Equilibrium Analysis”, background paper prepared for OECD, 2005.

Narlikan A. and D. Tussie (2004), "Bargaining Together in Cancún: Developing Countries and Their Evolving Coalitions”, World Economy, Volume 27, Issue 7, Page 947-966.

OECD (2005a), Global, national and household level effects of trade and agricultural policy reform.

OECD (2005b), OECD Review of Agricultural Policies: Brazil, OECD, Paris.

Tangermann S. (2005), “OECD Area Agricultural Policies and the Interests of Developing Countries”, American Journal of Agricultural Economics, Vol. 87, No. 5, pp. 1128-1144.

Valdés A. and A. McCalla (1999), "Issues, Interests and Options of Developing Countries,” presented at the joint World Bank and WTO Conference on Agriculture and the New Trade Agenda in the WTO 2000 Negotiations, October 1-2, 1999, Geneva, Switzerland. 15 


\section{ANNEX}

Table 5. Share of household type in agricultural production value, by sector

Per cent

\begin{tabular}{|c|c|c|c|c|c|c|c|}
\hline & \multirow{3}{*}{$\begin{array}{l}\text { Share in } \\
\text { total } \\
\text { production } \\
\text { value }\end{array}$} & \multicolumn{6}{|c|}{ Composition of production value } \\
\hline & & \multicolumn{5}{|c|}{ Family agriculture } & \multirow{2}{*}{$\begin{array}{l}\text { Commercial } \\
\text { farms }\end{array}$} \\
\hline & & 1 & 2 & 3 & 4 & Total & \\
\hline Cattle ranching & 16 & 2 & 2 & 7 & 13 & 24 & 76 \\
\hline Sugar cane & 12 & 1 & 0 & 2 & 7 & 10 & 90 \\
\hline Poultry & 11 & 6 & 3 & 9 & 22 & 40 & 60 \\
\hline Milk farming & 10 & 5 & 6 & 19 & 22 & 52 & 48 \\
\hline Soybeans & 10 & 2 & 1 & 7 & 21 & 31 & 69 \\
\hline Maize & 7 & 8 & 6 & 15 & 20 & 49 & 51 \\
\hline Coffee & 6 & 2 & 2 & 8 & 13 & 25 & 75 \\
\hline Hog farming & 4 & 7 & 4 & 15 & 33 & 59 & 41 \\
\hline Rice & 4 & 5 & 4 & 8 & 13 & 30 & 70 \\
\hline Manioc & 3 & 9 & 11 & 33 & 31 & 84 & 16 \\
\hline Forestry & 2 & 0 & 0 & 2 & 6 & 8 & 92 \\
\hline Beans & 2 & 15 & 12 & 23 & 17 & 67 & 33 \\
\hline Other fruits and vegetables & 2 & 5 & 4 & 15 & 35 & 59 & 41 \\
\hline Oranges & 2 & 3 & 2 & 7 & 15 & 27 & 73 \\
\hline Tobacco & 2 & 2 & 5 & 42 & 49 & 98 & 2 \\
\hline Vegetable products & 2 & 8 & 10 & 19 & 26 & 63 & 37 \\
\hline Bananas & 1 & 4 & 6 & 18 & 30 & 58 & 42 \\
\hline Tomatoes & 1 & 5 & 3 & 10 & 28 & 46 & 54 \\
\hline Cotton & 1 & 6 & 5 & 10 & 12 & 33 & 67 \\
\hline Grapes & 1 & 2 & 2 & 11 & 32 & 47 & 53 \\
\hline Other products & 3 & 4 & 3 & 10 & 20 & 37 & 63 \\
\hline Total & 100 & 4 & 3 & 11 & 19 & 37 & 63 \\
\hline
\end{tabular}

Source: USP SAM. 
Table 6. Share of farm income from each sector by household type

Per cent

\begin{tabular}{|c|c|c|c|c|c|c|}
\hline & \multirow{3}{*}{$\begin{array}{c}\text { Share in } \\
\text { total } \\
\text { production } \\
\text { value }\end{array}$} & \multicolumn{5}{|c|}{ Product share of farm income for the farm type } \\
\hline & & \multicolumn{4}{|c|}{ Family agriculture } & \multirow{2}{*}{$\begin{array}{l}\text { Commercial } \\
\text { farms }\end{array}$} \\
\hline & & 1 & 2 & 3 & 4 & \\
\hline Cattle ranching & 16 & 8 & 10 & 10 & 11 & 20 \\
\hline Sugar cane & 12 & 2 & 2 & 2 & 4 & 17 \\
\hline Poultry & 11 & 15 & 9 & 9 & 13 & 10 \\
\hline Milk farming & 10 & 13 & 16 & 18 & 12 & 8 \\
\hline Soybeans & 10 & 4 & 4 & 6 & 11 & 10 \\
\hline Maize & 7 & 14 & 12 & 10 & 8 & 6 \\
\hline Coffee & 6 & 3 & 4 & 4 & 4 & 7 \\
\hline Hog farming & 4 & 7 & 5 & 5 & 7 & 3 \\
\hline Rice & 4 & 4 & 4 & 3 & 3 & 4 \\
\hline Manioc & 3 & 6 & 9 & 8 & 4 & 0 \\
\hline Forestry & 2 & 0 & 0 & 0 & 1 & 4 \\
\hline Beans & 2 & 8 & 8 & 5 & 2 & 1 \\
\hline Other fruits and vegetables & 2 & 3 & 3 & 3 & 4 & 1 \\
\hline Oranges & 2 & 2 & 1 & 1 & 2 & 3 \\
\hline Tobacco & 2 & 1 & 2 & 7 & 5 & 0 \\
\hline Vegetable products & 2 & 3 & 5 & 3 & 2 & 1 \\
\hline Bananas & 1 & 1 & 2 & 2 & 2 & 1 \\
\hline Tomatoes & 1 & 1 & 1 & 1 & 1 & 1 \\
\hline Cotton & 1 & 1 & 1 & 1 & 1 & 1 \\
\hline Grapes & 1 & 0 & 0 & 1 & 1 & 1 \\
\hline Other products & 1 & 4 & 2 & 1 & 2 & 1 \\
\hline Total & 100 & 100 & 100 & 100 & 100 & 100 \\
\hline
\end{tabular}

Source: USP SAM. 
Table 7. Household expenditure patterns, 1996

\begin{tabular}{|c|c|c|c|c|c|c|c|c|c|c|}
\hline & \multirow{3}{*}{$\begin{array}{c}\text { Total } \\
\text { Expenditure } \\
\text { (BRL/month) }\end{array}$} & \multicolumn{9}{|c|}{ As a percentage of total current expenditures } \\
\hline & & \multicolumn{2}{|c|}{ Food } & \multirow{2}{*}{ Housing } & \multirow{2}{*}{ Clothing } & \multirow{2}{*}{ Transportation } & \multirow{2}{*}{ Health } & \multirow{2}{*}{ Education } & \multirow{2}{*}{$\begin{array}{c}\text { Other } \\
\text { Consumption }\end{array}$} & \multirow{2}{*}{$\begin{array}{l}\text { Other } \\
\text { Current }\end{array}$} \\
\hline & & Monetary & Non-Monetary & & & & & & & \\
\hline Family agriculture 1 & 45.7 & 44 & 24 & 9 & 5 & 5 & 6 & & 1 & 1 \\
\hline Family agriculture 2 & 58.0 & 42 & 19 & 13 & 5 & 3 & 8 & & 1 & 1 \\
\hline Family agriculture 3 & 73.6 & 36 & 18 & 14 & 6 & 5 & 9 & & 2 & 3 \\
\hline Family agriculture 4 & 170.9 & 24 & 6 & 22 & 5 & 11 & 8 & & 11 & 9 \\
\hline Business agriculture & 209.4 & 24 & 8 & 22 & 5 & 10 & 10 & & 4 & 7 \\
\hline Agricultural employees & 77.4 & 37 & 9 & 19 & 5 & 5 & 7 & & 2 & 7 \\
\hline Urban household 1 & 78.9 & 40 & 3 & 24 & & 4 & 7 & & 5 & 4 \\
\hline Urban household 2 & 110.4 & 39 & 2 & 27 & 5 & 4 & 7 & & 4 & 4 \\
\hline Urban household 3 & 184.2 & 31 & 1 & 26 & 6 & 8 & 7 & & 5 & 7 \\
\hline Urban household 4 & 500.2 & 19 & 0 & 30 & 4 & 9 & 8 & & 9 & 12 \\
\hline
\end{tabular}

Source: PPV 1996 microdata. 
Table 8. Baseline Factor Incomes and Changes

\begin{tabular}{|c|c|c|c|c|c|}
\hline & \multirow{2}{*}{$\begin{array}{l}\text { Baseline } \\
\text { USD million }\end{array}$} & $\begin{array}{l}\text { Full } \\
\text { employment }\end{array}$ & $\begin{array}{l}\text { Full employment } \\
\text { /fiscal neutrality }\end{array}$ & Unemployment & $\begin{array}{l}\text { Unemployment/ } \\
\text { fiscal neutrality }\end{array}$ \\
\hline & & \multicolumn{4}{|c|}{ Change (\%) } \\
\hline Capital family agriculture 1 & 91 & 3.67 & 3.71 & 3.74 & 3.64 \\
\hline Capital family agriculture 2 & 87 & 3.66 & 3.67 & 3.69 & 3.64 \\
\hline Capital family agriculture 3 & 258 & 3.84 & 3.88 & 3.9 & 3.82 \\
\hline Capital family agriculture 4 & 402 & 4.33 & 4.47 & 4.49 & 4.31 \\
\hline Capital business agriculture & 893 & 4.76 & 4.95 & 4.97 & 4.74 \\
\hline Capital urban 1 & 811 & 1.05 & 1.3 & 1.3 & 1.05 \\
\hline Capital urban 2 & 1713 & 0.96 & 1.19 & 1.19 & 0.96 \\
\hline Capital urban 3 & 3128 & 0.93 & 1.16 & 1.16 & 0.93 \\
\hline Capital urban 4 & 1825 & 0.96 & 1.2 & 1.2 & 0.96 \\
\hline Labor family agriculture 1 & 225 & 1.57 & 1.47 & 1.47 & 1.58 \\
\hline Labor family agriculture 2 & 195 & 1.63 & 1.49 & 1.49 & 1.63 \\
\hline Labor family agriculture 3 & 354 & 1.93 & 2.17 & 2.17 & 1.93 \\
\hline Labor family agriculture 4 & 517 & 2.16 & 2.43 & 2.43 & 2.16 \\
\hline Labor agriculture employees & 935 & 4.44 & 3.69 & 3.7 & 4.42 \\
\hline Labor urban 1 & 925 & 1.25 & 1.23 & 1.22 & 1.26 \\
\hline Labor urban 2 & 2329 & 1.28 & 1.24 & 1.24 & 1.29 \\
\hline Labor urban 3 & 4394 & 1.3 & 1.57 & 1.57 & 1.3 \\
\hline Labor urban 4 & 1129 & 1.23 & 1.5 & 1.5 & 1.23 \\
\hline Land family agriculture 1 & 46 & 3.67 & 3.71 & 3.74 & 3.64 \\
\hline Land family agriculture 2 & 43 & 3.66 & 3.67 & 3.69 & 3.64 \\
\hline Land family agriculture 3 & 129 & 3.84 & 3.88 & 3.9 & 3.82 \\
\hline Land family agriculture 4 & 201 & 4.33 & 4.47 & 4.49 & 4.31 \\
\hline Land business agriculture & 445 & 4.76 & 4.96 & 4.97 & 4.74 \\
\hline
\end{tabular}

Source: Simulation results. 
Table 9. Household incomes

\begin{tabular}{|c|c|c|c|c|c|}
\hline & \multirow{2}{*}{$\begin{array}{c}\text { Baseline } \\
\text { USD million }\end{array}$} & $\begin{array}{l}\text { Full } \\
\text { employment }\end{array}$ & $\begin{array}{l}\text { Full employment } \\
\text { /fiscal neutrality }\end{array}$ & Unemployment & $\begin{array}{l}\text { Unemployment/ } \\
\text { fiscal neutrality }\end{array}$ \\
\hline & & \multicolumn{4}{|c|}{ Change (\%) } \\
\hline Family agriculture 1 & 350 & 1.72 & 2.09 & 1.70 & 2.07 \\
\hline Family agriculture 2 & 357 & 1.54 & 1.89 & 1.52 & 1.86 \\
\hline Family agriculture 3 & 849 & 1.62 & 2.07 & 1.79 & 2.22 \\
\hline Family agriculture 4 & 1156 & 1.91 & 2.42 & 2.11 & 2.60 \\
\hline Business agriculture & 870 & 2.80 & 4.29 & 3.03 & 4.46 \\
\hline Agricultural employees & 1044 & 3.96 & 3.98 & 3.30 & 3.32 \\
\hline Urban household 1 & 1627 & 0.62 & 1.09 & 0.69 & 1.14 \\
\hline Urban household 2 & 3936 & 0.68 & 1.08 & 0.73 & 1.13 \\
\hline Urban household 3 & 7380 & 0.69 & 1.09 & 0.93 & 1.31 \\
\hline Urban household 4 & 2653 & 0.39 & 1.04 & 0.63 & 1.26 \\
\hline
\end{tabular}

Source: Simulation results. 
Table 10. Changes in purchaser prices

Per cent

\begin{tabular}{|c|c|c|c|c|}
\hline & $\begin{array}{c}\text { Full } \\
\text { employment }\end{array}$ & $\begin{array}{l}\text { Full employment } \\
\text { /fiscal neutrality }\end{array}$ & Unemployment & $\begin{array}{l}\text { Unemployment/ } \\
\text { fiscal neutrality }\end{array}$ \\
\hline Coffee & 5.28 & 5.28 & 4.98 & 4.97 \\
\hline Sugar cane & 2.85 & 2.87 & 2.23 & 2.23 \\
\hline Rice & -2.65 & -2.66 & -1.67 & -1.68 \\
\hline Wheat & -0.44 & -0.44 & -0.41 & -0.41 \\
\hline Soybean & -0.58 & -0.56 & -1.34 & -1.33 \\
\hline Maize & 1.49 & 1.50 & 0.98 & 0.99 \\
\hline Beans & 5.34 & 5.35 & 5.72 & 5.73 \\
\hline Cassava & 4.31 & 4.30 & 4.60 & 4.60 \\
\hline Oranges & 2.65 & 2.66 & 1.60 & 1.60 \\
\hline Other fruits and vegetables & 3.10 & 3.12 & 2.51 & 2.52 \\
\hline Cotton & 11.15 & 11.10 & 11.95 & 11.90 \\
\hline Other crops & 3.15 & 3.18 & 1.69 & 1.71 \\
\hline Poultry and egg production & 1.66 & 1.67 & 1.05 & 1.06 \\
\hline Cattle ranching and farming & 4.20 & 4.21 & 3.54 & 3.54 \\
\hline Hog and pig farming & 2.13 & 2.14 & 1.51 & 1.51 \\
\hline Milk farming & 0.07 & 0.10 & -0.90 & -0.87 \\
\hline Other animal production & 2.63 & 2.64 & 1.87 & 1.88 \\
\hline Coffee products & 2.69 & 2.68 & 2.48 & 2.47 \\
\hline Alcohol & 0.85 & 0.85 & 0.70 & 0.70 \\
\hline Sugar & -3.94 & -3.93 & -4.32 & -4.31 \\
\hline Rice products & -3.93 & -3.87 & -4.23 & -4.18 \\
\hline Wheat flour & 1.21 & 1.18 & 1.20 & 1.17 \\
\hline Vegetable oil & -2.70 & -2.69 & -3.13 & -3.13 \\
\hline Other vegetables & 0.01 & 0.02 & -0.14 & -0.13 \\
\hline Poultry products & -0.65 & -0.64 & -1.05 & -1.04 \\
\hline Beef products & 2.02 & 2.02 & 1.55 & 1.55 \\
\hline Other meat products & 0.84 & 0.84 & 0.41 & 0.42 \\
\hline Dairy products & -0.15 & -0.14 & -0.57 & -0.56 \\
\hline Animal feed & -0.49 & -0.49 & -0.55 & -0.55 \\
\hline Other food products & -0.81 & -0.81 & -0.96 & -0.96 \\
\hline Beverage & -1.03 & -1.03 & -1.02 & -1.02 \\
\hline Textiles & 1.96 & 1.96 & 1.97 & 1.97 \\
\hline Tractors products & -3.63 & -3.64 & -3.47 & -3.47 \\
\hline Fertilisers products & -0.27 & -0.27 & -0.17 & -0.17 \\
\hline Agricultural defensives products & 0.04 & 0.05 & -0.10 & -0.09 \\
\hline Resource oriented products & -0.83 & -0.83 & -0.69 & -0.69 \\
\hline Other industrial products & -1.45 & -1.45 & -1.32 & -1.32 \\
\hline Trade & 0.26 & 0.26 & 0.33 & 0.32 \\
\hline Transport & -0.50 & -0.51 & -0.35 & -0.35 \\
\hline Services and government & 0.63 & 0.63 & 0.72 & 0.72 \\
\hline
\end{tabular}

Source: Simulation results. 
Table 11. Household consumption expenditure shares by broad commodity group

Per cent

\begin{tabular}{|c|c|c|c|c|}
\hline & Agriculture & Food & Manufacturing & Services \\
\hline Family agriculture 1 & 20 & 43 & 21 & 16 \\
\hline Family agriculture 2 & 17 & 41 & 26 & 16 \\
\hline Family agriculture 3 & 14 & 36 & 30 & 20 \\
\hline Family agriculture 4 & 6 & 17 & 28 & 49 \\
\hline Business agriculture & 8 & 17 & 32 & 43 \\
\hline Agricultural employees & 9 & 31 & 30 & 30 \\
\hline Urban household 1 & 9 & 29 & 27 & 35 \\
\hline Urban household 2 & 6 & 23 & 29 & 41 \\
\hline Urban household 3 & 5 & 17 & 29 & 49 \\
\hline Urban household 4 & 3 & 8 & 22 & 67 \\
\hline
\end{tabular}

Source: USP SAM. 
Table 12. Changes in Brazilian exports

Per cent

\begin{tabular}{|c|c|c|c|c|}
\hline & $\begin{array}{c}\text { Full } \\
\text { employment }\end{array}$ & $\begin{array}{l}\text { Full employment } \\
\text { /fiscal neutrality }\end{array}$ & Unemployment & $\begin{array}{l}\text { Unemployment/ } \\
\text { fiscal neutrality }\end{array}$ \\
\hline Soybean & 27.52 & 27.49 & 30.86 & 30.84 \\
\hline Maize & 12.55 & 12.56 & 13.71 & 13.72 \\
\hline Beans & -0.33 & -0.33 & -0.78 & -0.78 \\
\hline Oranges & 8.21 & 8.2 & 10.8 & 10.8 \\
\hline Other fruits and vegetables & 7.07 & 7.04 & 8.6 & 8.58 \\
\hline Other crops & 8.34 & 8.29 & 11.81 & 11.77 \\
\hline Poultry and egg production & 12.29 & 12.28 & 14.11 & 14.1 \\
\hline Cattle ranching and farming & 13.62 & 13.61 & 15.47 & 15.48 \\
\hline Other animal production & 11.54 & 11.53 & 13.53 & 13.53 \\
\hline Coffee products & 3.31 & 3.32 & 4.12 & 4.12 \\
\hline Alcohol & 16.07 & 16.05 & 16.73 & 16.72 \\
\hline Sugar & 29.98 & 29.97 & 31.72 & 31.72 \\
\hline Rice products & 25.89 & 25.75 & 27.21 & 27.08 \\
\hline Wheat flour & 5.55 & 5.63 & 5.93 & 6.01 \\
\hline Vegetable oil & 25.57 & 25.56 & 27.31 & 27.31 \\
\hline Other vegetables & 12.57 & 12.57 & 13.24 & 13.25 \\
\hline Poultry products & 21.62 & 21.62 & 22.93 & 22.93 \\
\hline Beef products & 17.37 & 17.37 & 18.86 & 18.87 \\
\hline Other meat products & 18.7 & 18.73 & 20.11 & 20.14 \\
\hline Dairy products & 9.05 & 9.03 & 10.51 & 10.49 \\
\hline Animal feed & 18.41 & 18.43 & 18.52 & 18.54 \\
\hline Other food products & 15.27 & 15.28 & 15.96 & 15.97 \\
\hline Beverage & 12.71 & 12.73 & 13.05 & 13.06 \\
\hline Textiles & 5.26 & 5.28 & 5.57 & 5.59 \\
\hline Tractors products & 12.19 & 12.19 & 11.8 & 11.81 \\
\hline Fertilizers products & 20.24 & 20.26 & 19.65 & 19.68 \\
\hline Agricultural defensives products & 9.93 & 9.93 & 10.14 & 10.13 \\
\hline Resource oriented products & 11.32 & 11.33 & 11.13 & 11.13 \\
\hline Other industrial products & 10.53 & 10.53 & 10.44 & 10.44 \\
\hline Trade & 12.54 & 12.54 & 12.72 & 12.72 \\
\hline Transport & 14.28 & 14.28 & 14.24 & 14.24 \\
\hline Services and government & 9.71 & 9.71 & 9.83 & 9.82 \\
\hline
\end{tabular}

Source: Simulation results. 
Table 13. Changes in Brazilian imports

Per cent

\begin{tabular}{|c|c|c|c|c|}
\hline & $\begin{array}{c}\text { Full } \\
\text { employment }\end{array}$ & $\begin{array}{l}\text { Full employment } \\
\text { /fiscal neutrality }\end{array}$ & Unemployment & $\begin{array}{l}\text { Unemployment/ } \\
\text { fiscal neutrality }\end{array}$ \\
\hline Rice & -0.15 & -0.15 & 2.04 & 2.04 \\
\hline Wheat & 3.27 & 3.29 & 3.24 & 3.26 \\
\hline Soybean & 3.10 & 3.13 & 2.30 & 2.32 \\
\hline Maize & 4.58 & 4.62 & 3.28 & 3.32 \\
\hline Beans & 17.30 & 17.33 & 18.25 & 18.28 \\
\hline Cassava & 14.81 & 14.80 & 15.55 & 15.55 \\
\hline Oranges & 9.96 & 9.98 & 7.75 & 7.76 \\
\hline Other fruits and vegetables & 10.97 & 11.02 & 9.71 & 9.76 \\
\hline Other crops & 12.37 & 12.45 & 9.21 & 9.28 \\
\hline Poultry and egg production & 4.67 & 4.70 & 3.65 & 3.67 \\
\hline Cattle ranching and farming & 4.99 & 5.00 & 3.82 & 3.83 \\
\hline Hog and pig farming & 4.47 & 4.54 & 3.65 & 3.72 \\
\hline Other animal production & 8.55 & 8.60 & 6.99 & 7.03 \\
\hline Coffee products & 6.73 & 6.73 & 6.48 & 6.48 \\
\hline Alcohol & 4.95 & 4.95 & 4.73 & 4.73 \\
\hline Sugar & -7.76 & -7.74 & -8.18 & -8.16 \\
\hline Rice products & -1.00 & -0.85 & -1.56 & -1.42 \\
\hline Wheat flour & 5.26 & 5.21 & 5.40 & 5.36 \\
\hline Vegetable oil & 3.57 & 3.61 & 2.87 & 2.90 \\
\hline Other vegetables & 21.37 & 21.40 & 21.07 & 21.10 \\
\hline Poultry products & 228.35 & 228.45 & 225.90 & 225.98 \\
\hline Beef products & 5.17 & 5.19 & 4.34 & 4.35 \\
\hline Other meat products & 4.59 & 4.64 & 3.82 & 3.87 \\
\hline Dairy products & 3.61 & 3.65 & 2.88 & 2.92 \\
\hline Animal feed & 14.02 & 14.03 & 13.60 & 13.61 \\
\hline Other food products & 12.80 & 12.81 & 12.50 & 12.51 \\
\hline Beverages & 35.97 & 35.97 & 36.17 & 36.17 \\
\hline Textiles & 10.46 & 10.45 & 10.60 & 10.59 \\
\hline Tractors products & 7.97 & 7.97 & 8.51 & 8.51 \\
\hline Fertilisers products & 12.38 & 12.41 & 12.09 & 12.11 \\
\hline Agricultural defensives products & 25.18 & 25.23 & 24.23 & 24.27 \\
\hline Resource oriented products & 7.13 & 7.13 & 7.48 & 7.49 \\
\hline Other industrial products & 13.95 & 13.95 & 14.31 & 14.31 \\
\hline Trade & 2.02 & 2.02 & 2.25 & 2.25 \\
\hline Services and government & 5.90 & 5.89 & 6.17 & 6.16 \\
\hline
\end{tabular}

Source: Simulation results. 
Table 14. Price of value added

Per cent changes

Full employment $\begin{aligned} & \text { Full employment } \\ & \text { /fiscal neutrality } \quad \text { Unemployment }\end{aligned} \quad \begin{aligned} & \text { Unemployment/ } \\ & \text { fiscal neutrality }\end{aligned}$

\begin{tabular}{|c|c|c|c|c|}
\hline Sugar cane & 4.41 & 4.43 & 3.48 & 3.49 \\
\hline Soybean & 4.29 & 4.31 & 3.14 & 3.16 \\
\hline Maize & 4.14 & 4.16 & 2.82 & 2.83 \\
\hline Fruits & 4.28 & 4.29 & 3.35 & 3.36 \\
\hline Other crops & 4.22 & 4.24 & 3.30 & 3.31 \\
\hline Poultry and egg production & 4.24 & 4.26 & 3.14 & 3.15 \\
\hline Cattle ranching and farming & 4.26 & 4.28 & 3.22 & 3.24 \\
\hline Hog and pig farming & 4.17 & 4.19 & 3.09 & 3.11 \\
\hline Other animal production & 4.13 & 4.15 & 3.04 & 3.06 \\
\hline Coffee industries & 1.02 & 1.02 & 1.19 & 1.19 \\
\hline Alcohol & 1.01 & 1.01 & 1.23 & 1.23 \\
\hline Sugar & 1.17 & 1.17 & 1.17 & 1.17 \\
\hline Vegetable oil processing & 1.00 & 1.00 & 1.19 & 1.19 \\
\hline Vegetable products processing & 1.06 & 1.05 & 1.18 & 1.18 \\
\hline Poultry industries & 1.06 & 1.06 & 1.18 & 1.18 \\
\hline Beef industries & 1.10 & 1.10 & 1.18 & 1.18 \\
\hline Other meat industries & 1.14 & 1.14 & 1.18 & 1.17 \\
\hline Dairy industries & 1.06 & 1.05 & 1.18 & 1.18 \\
\hline Animal feed & 1.08 & 1.08 & 1.18 & 1.18 \\
\hline Other food products & 1.11 & 1.10 & 1.18 & 1.18 \\
\hline Beverages & 1.08 & 1.08 & 1.27 & 1.27 \\
\hline Textiles & 1.11 & 1.11 & 1.14 & 1.13 \\
\hline Agricultural machinery industries & 1.16 & 1.15 & 1.38 & 1.38 \\
\hline Fertilisers & 1.17 & 1.16 & 1.34 & 1.33 \\
\hline Other chemical elements & 1.06 & 1.05 & 1.26 & 1.26 \\
\hline Resource oriented industries & 1.02 & 1.01 & 1.22 & 1.22 \\
\hline Other industries & 1.05 & 1.05 & 1.21 & 1.21 \\
\hline Trade & 1.14 & 1.14 & 1.20 & 1.20 \\
\hline Transport & 1.15 & 1.14 & 1.33 & 1.33 \\
\hline Services and government & 1.14 & 1.14 & 1.24 & 1.24 \\
\hline
\end{tabular}

Source: Simulation results. 